\title{
PEDAGOGICAL CONDITIONS OF MEDIA EDUCATION IN PRIMARY SCHOOL
}

\author{
GAYANE YEGANYAN \\ Armenian State Pedagogical University after Kh. Abovyan, \\ Chair of Pedagogy, \\ PhD of Pedagogical Sciences \\ BETTY KILERJIAN \\ Armenian State Pedagogical University after Kh. Abovyan, \\ Chair of Pedagogy, Master's degreestudent
}

https://doi.org/10.52853/25792903-2021.2-gybk

\section{Abstract}

The media and its use in the educational process, which has global importance, are the twenty-first century's challenge. In the pedagogical process, media education is addressed to each child within the context of any subject, ensuring the academic subject's required objectives and successful instructional activity, as well as the final results.

Media is a tool in the pedagogical process for early learning games, aesthetic education, language skills, mathematics, religion or ethics. It is not enough to have the developed equipment to use the media. In elementary school, the classroom equipped with appropriate media is more attractive for the students; it will facilitate the educational, developing and upbringing process and make it more stimulating.

For the development of imagination, creativity, and independent search skills in elementary school, the supervised use of media during the educational process is particularly important. The media equipment is selected in accordance with the secondary school's curricul um, with targets set and the experience eval uated regularly. The controlled use of technological equipment is necessary in this case Students' cognitive and artistic skills might be harmed by excessive media use in elementary school.

It is justified that today's primary school students are extremely informed due to the media, their thinking skills are more developed. Today, there is a need for parent-teacher support processes for the child, strict content control, and pedagogical guidance from computer \& Internet prevention.

The use of technologies in the educational process is one of the urgent problems of modern pedagogy. The introduction of media technology in primary school has both advantages and disadvantages. Media education helps students navigate the information. They contribute to the development of positive motivation for learning, activate the cognitive, research and creative activities of younger schoolchildren, but can harm their heal th and negatively affect their worldview.

The fact is that the 21st century is the age of high technologies. Therefore, education, which provides a high level of general knowledge, should be replaced by 
education focused on the creative development of each student's personality. Therefore, today it is necessary to revise the content of higher education, methods and types of education, that is, to apply pedagogical innovation.

K eywords and phrases: media education, elementary school, media literacy, media tools, media competencies, pedagogical conditions.

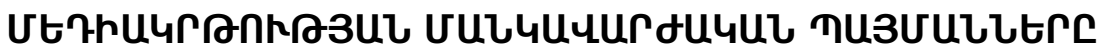 surruuu乙 qтกnsnkU
}

\author{
qu3uఒt t9u孔3ul

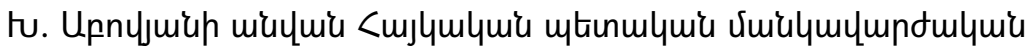 \\ <múumumpuiz,

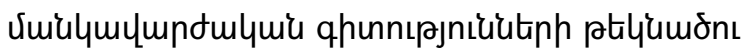

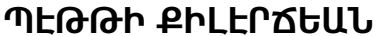

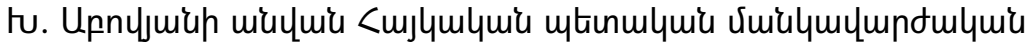
<múupumpuiup vimqhuinnnu

\section{Cuviunnunuqhp}

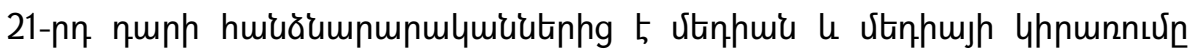

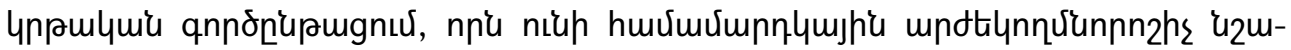

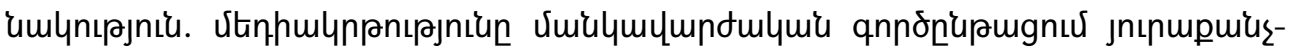

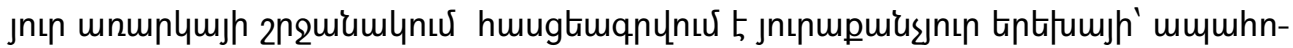

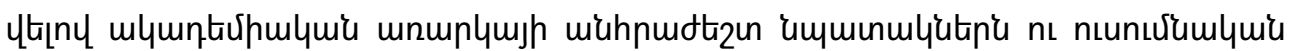

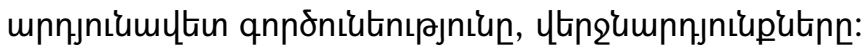

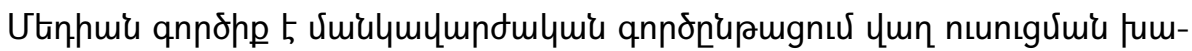

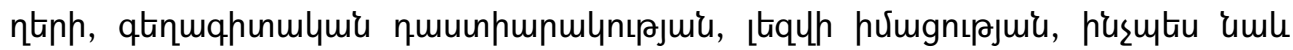

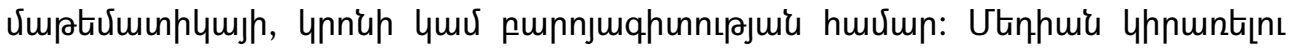

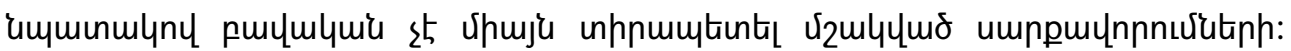

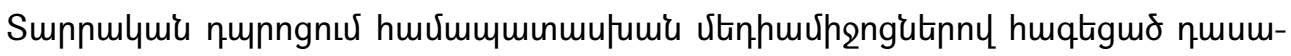

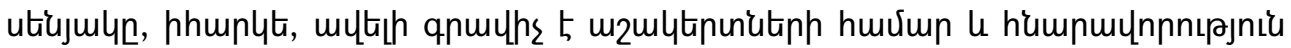

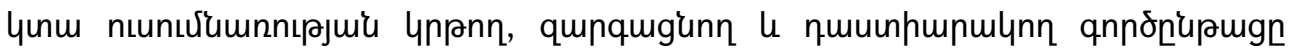

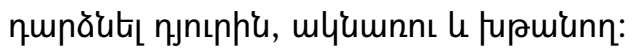




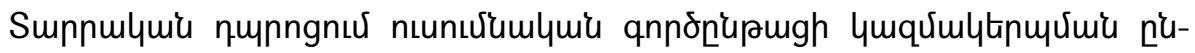

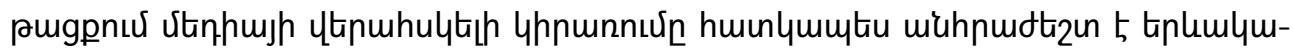

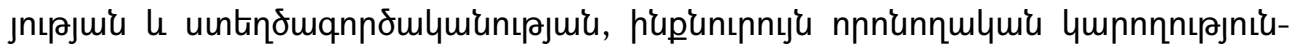

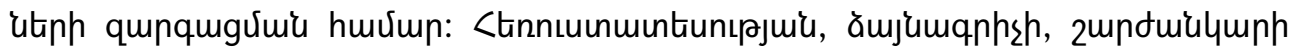

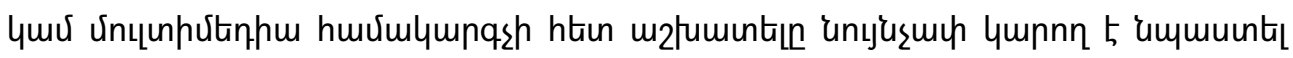

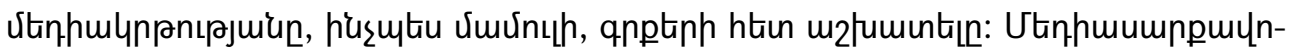

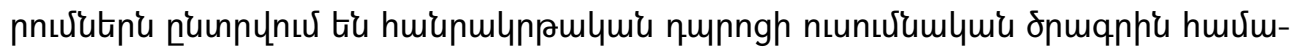

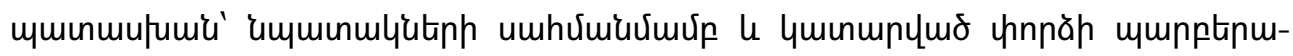

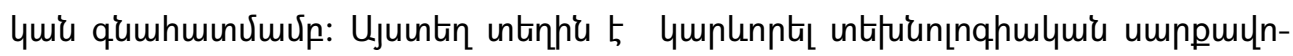

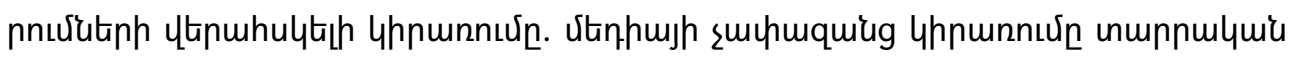

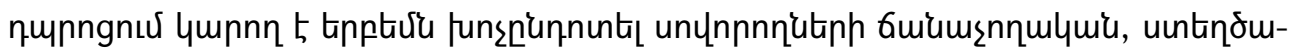

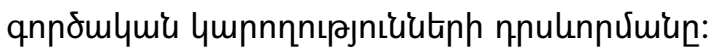

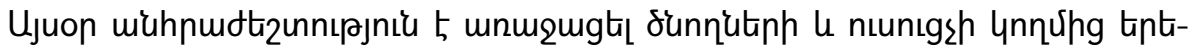

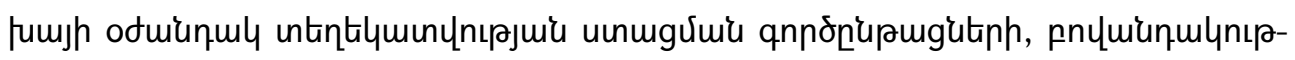

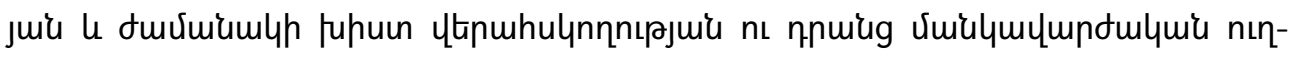

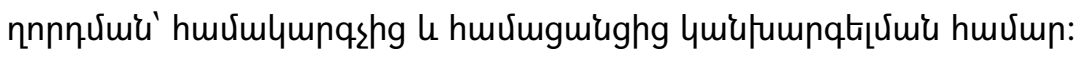

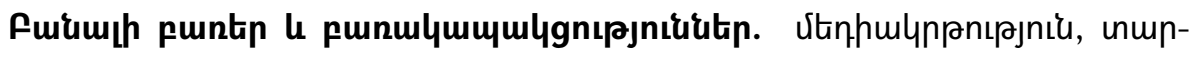

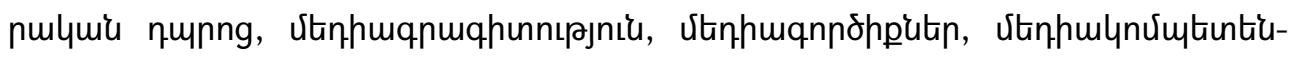

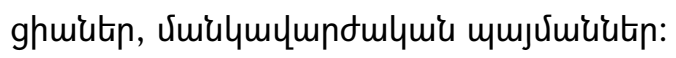

\section{ПЕДАГОГИЧЕСКИЕ УСЛОВИЯ МЕДИА-ОБРАЗОВАНИЯ В НАЧАЛЬНОЙ ШКОЛЕ}

\section{ГАЯНЕ ЕГАНЯН}

Армянский государственный педагогический университет имени

Х. Абовяна, кафедра педагогики, кандидат педагогических наук

\section{БЕТТИ КИЛЕРДЖЯН}

Армянский государственный педагогический университет имени

Х. Абовяна

кафедра педагогики,

магистр 


\section{Аннотация}

Задача XXI века - медиа и его применение в образовательном процессе, имеющее общечеловеческие ориентированность и значение. Медиа-образование, применяемое в педагогическом процессе, адресовано каждому ребенку в рамках каждого предмета, обеспечивает необходимые цели учебного предмета и эффективную учебную деятельность, финальные результаты.

Медиа - это инструмент в педагогическом процессе, необходимый для игр в раннем возрасте, эстетического воспитания, языковых навыков, а также изучения таких предметов, как математика, религия или этика. Для использования медиа недостаточно иметь только оборудование. В начальной школе класс, оборудованный соответствующими медиа- средствами, конечно, будет являться более привлекательным для учеников, он поможет сделать учебный процесс более легким, очевидным и мотивирующим.

Контролируемое использование медиа при организации учебного процесса в начальной школе особенно необходимо для развития воображения, творческих способностей и навыков самостоятельного поиска. Медиа-оборудование выбирается в соответствии с учебной программой средней школы, путем постановки целей и регулярной оценки опыта. Здесь уместно контролировать использование технологического оборудования. Чрезмерное использование медиа-средств в начальной школе может иногда мешать развитию когнитивных и творческих способностей учащихся.

Обосновано, что сегодняшние ученики начальных классов чрезвычайно информированы о СМИ в строгом контроле со стороны родителей и учителей над содержанием и временем получкеия ребенком дополнительный информации и при необходимости - в ограничении или даже запрете использования компютера и интернета.

Использование технологий в учебном процессе - одна из актуальных проблем современной педагогики. Внедрение медиа-технологий в начальной школе имеет как преимущества, так и недостатки. Медиа-образование помогает студентам ориентироваться в информации. Оно способствует развитию положительной мотивации к обучению, активизирует познавательную, исследовательскую и творческую деятельность младших школьников, но может нанести вред их здоровью и негативно повлиять на их мировоззрение.

Дело в том, что XXI век - век высоких технологий. Образование, предполагающее высокий уровень общих знаний, должно быть заменено образованием, ориентированным на творческое развитие личности каждого учащегося. Поэтому сегодня необходимо пересмотреть содержание высшего образования, методы и виды обучения, то есть применить педагогические новшества. 
Ключевые слова и словосочетания: медиа-образование, начальная школа, медиа грамотность, медиа-инструменты, медиа-компетенции, педагогические условия.

\section{Introduction}

In the pedagogical process, media education and media literacy presuppose understanding, mastery, and application of various means, technologies, and tools in support of teaching and educating. The term "media" is borrowed from Latin (media or medium), which means "means, trick, method, mediator". Thus, any medium that transmits and disseminates knowledge, from ancient petroglyphs, old parchments, traditional books, works of art to state-of-theart technology produced due to technological progress, can be considered a media text or media document in this context. [4 p. 43].

In elementary school, media is used to pique students' attention while enhancing cultural, interpersonal, and relationship skills. In addition, it aids in the establishment of close links between elementary school and real life, "overcoming the school's detachment from the media, that is, establishing close ties with the realities of life" [1, p. 5].

Media education is of vital importance nowadays. "Media education can be considered to play an important role in the success of the school curricul um" [3, p. 13]. Children, learners or citizens of the 21st century are surrounded by the media, a key component of their social and cultural landscape Auditory, visual, and written messages are continually aimed at affecting their awareness, thoughts, emotions, attitudes, or behaviours. Unfortunately, the majority of students are unaware of how to construct these messages. "The primary aim of media education in elementary school is to promote the ability to live in a modern information-rich world, to participate in a variety of activities, and to interact in the field of media culture while adhering to etiquette." [5, para. 43].

\section{Methodological basis}

The studies of A. Topuzyan, J. Gyulamiryan, S. Asatryan, L. Poghosyan, N. Karapetyan, and L. Avagyan on the topic of media education in elementary school, the theoretical provisions of A. Manukyan and $\mathrm{H}$. Muradyan on media education, as well as grounded theoretical reviews of a variety of international theorists and pedagogical views, formed the methodological basis of this paper.

Study methods.

- Study of research literature,

- Questionnaire. 


\section{R esults and Discussion of the findings}

Our study aims to determine the state of media education in the elementary school setting. We conducted research using contemporary scientific-pedagogical literature, electronic materials, and a questionnaire.

The research was conducted with 38 students from the National School in Aleppo, Syria, and 29 students from Medovka Secondary School in Lori Region in order to identify the problem

We tried to find out what steps teachers use in the educational process by conducting a questionnaire survey with 67 students from Aleppo and Medovka schools.

The results of a questionnaire survey given to students at Medovka Secondary School, Lori Region, and Aleppo National School are presented below.
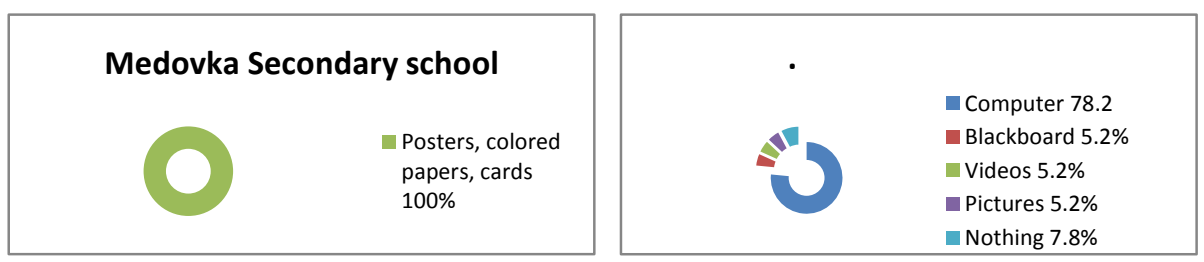

\section{Graphic 1. A pplication of resources used by the teacher according to the students}

The findings show that Medovka teachers do not use media tools in the educational process, which is frustrating because media tools should be used in elementary school, triggering all learners' senses.

While we see the Aleppo school's pedagogues attempting to use ICTs in the classroom, they likely use media resources based on the provision of pedagogical requirements, taking into account the students' age differences.

- $\quad$ Next is the answer to the question: "Do they prefer the instructor to use media during class, and if so, why?"

\begin{tabular}{|r|r|}
\hline Medovka Secondary School & Aleppo National School \\
\hline Yes 86.2\% & $\square$ Yes $92.1 \%$ \\
No 13.7\% & No $7.1 \%$ \\
\hline
\end{tabular}

G raphic 2: Preference for the use of media in the classroom

The percentage of media preferences among Medovka students is low. The students responded that the lesson would be simpler, more impressive, informative, and comprehensible if the media were used in the classroom In contrast, the students who 
responded negatively believed that media distracts them and that the traditional lesson is easier due to their unfamiliarity with the media tools.

The percentage of media use among Aleppo students is higher in the teaching process. The students responded that using media in the classroom makes the lesson simpler, more impressive, engaging, and understandable, while 7.1 per cent of students with a negative attitude believed that media distracts them and that traditional teaching is simpler; this is due to the fact, that they are familiar with media resources and use them in their everyday lives.

The answer got to the following question "Do they use Smart tools?"
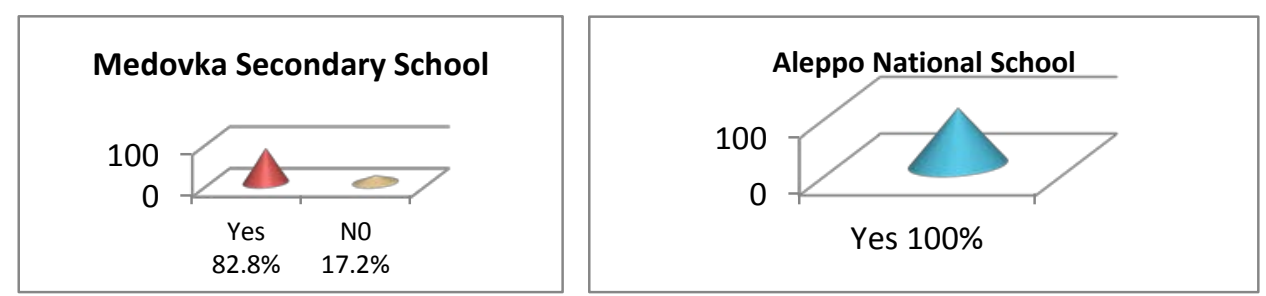

\section{Graphic 3. Smart tools usage by pupils}

Because of a lack of Smart tools, $17.2 \%$ of Medovka students do not use them, despite the fact that using them is now necessary. $100 \%$ of Aleppo students use Smart tools. Although using these tools is timeconsuming, it is worrying when $100 \%$ of elementary school students use them

- $\quad$ Are there any specific limits on the use of media tools at home during the day for them?

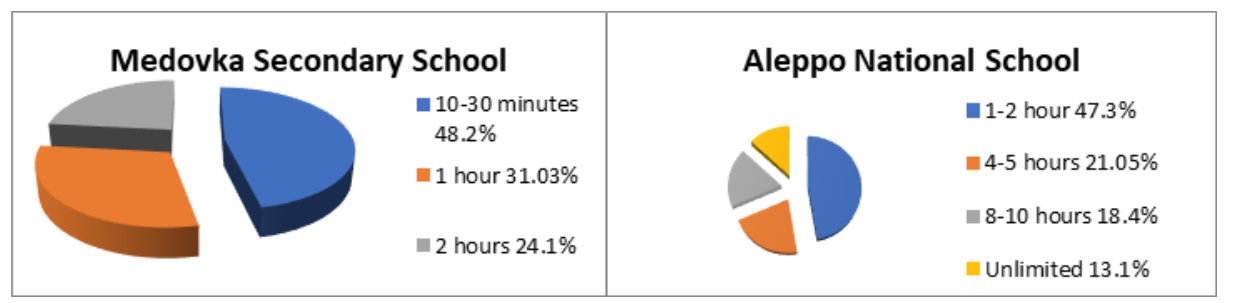

\section{Graphic 4. Student media usage time during the day}

Given that the strictly specified period for elementary school students is half an hour, 48.2 per cent of Medovka students' responses were welcome. For the other 31.03 per cent to 24.1 per cent of students, parents have to find another necessary occupation.

The responses of Aleppo students concern, especially because of the age peculiarity of elementary school students, who are highly dependent, which can lead to serious health problems. There is a lot of work to be done here with educators and parents to help students use the appropriate literate media.

- To the next question, who controls the media, the pupils answered: 


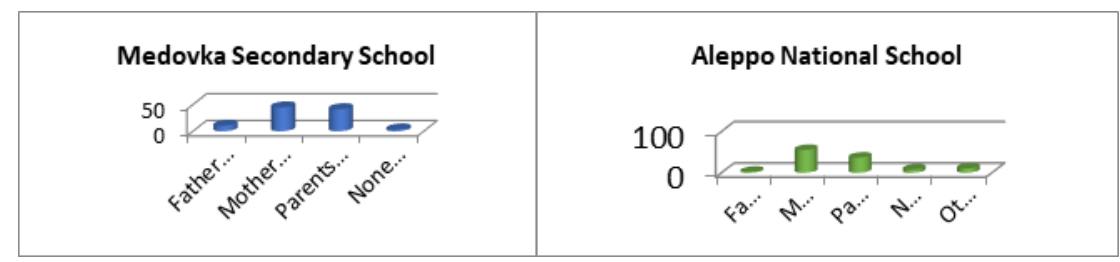

\section{Graphic 5. M edia usage supervisors}

According to the survey, in most cases, the mother controls the students' occupation of both schools, both parents are in second place, and the father is in third place. The supervision of the father and mother is welcomed; here, we see the high indicator. Teachers are expected to collaborate with parents to ensure that they know the correct use of media and its drawbacks and control necessity.

The primary challenge of the 21st-century public school is to pedagogize the process of media education. So the competencies teachers should have to use the targeted, and effective media education and technology are of great importance. "Future educators must be media literate, that is, able to search, find, process information, adapt and interpret it to pass it on to another addressee (student) [2, p. 51].

\section{Conclusion}

We propose the following pedagogical conditions for primary school media education based on theoretical and research findings.

- A pedagogical team that is media literate.

- Teachers' knowledge and use of special approaches to ensure primary school students' media literacy.

- A ppropriate media forms for the subject and goals of the lesson.

- Physical requirements for media usage in the pedagogical process: lighting, sound, ventilation, heating, suitable media furniture, and property.

- Media use of educational and extracurricular activities.

- Creating an active, welcoming environment for the use of media in primary schools.

- Usage of media resources that are suitable for primary school students' age and cognitive interests.

- Allowing primary school students to watch, debate, maketheir own decisions and use the media.

- Pedagogical conditions and situation provision for students' media knowledge, analysis, and production of media content. 
- Organizing workshops and webi nars ai med at educating parents about media culture.

- Ensure that students and their parents are aware of etiquetterules.

\section{REFERENCES}

1. Fedorov A., Media Education Literacy in the World: Trends, European Researcher, Vol. [67], № 1-2, 2014, 12 pages:

2. Concept of Pedagogical Education, Armenian State Pedagogical University after Kh. Abovyan, Research Center, Y erevan, 2014, 84 pages.

3. Frau-Meigs D., Media Education A Kit for Teachers, Students, Parents and Professionals, UNESCO - 2006, 188 pages:

4. Manukyan A. M., Muradyan H. S., Media Education, Educational-methodical manual for students, postgraduates, media teachers, media psychologists and media consumers of pedagogical universities, Y erevan, "Zangak" publishing house, 2017, 272 pages.

5. Topuzyan A. O., Gyulamiryan J. H., Asatryan S. M., Poghosyan L. M., Karapetyan N. Z., Avagyan L. M., "Media Education in Elementary School" Educational-methodical manual for teachers and parents. - Yerevan, "Pedagogue" publishing house, 2019, 140 pages.

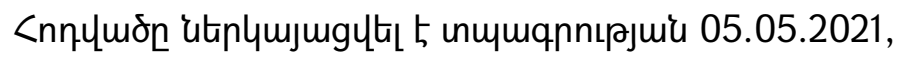

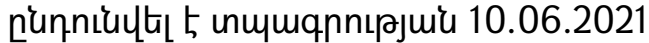

